\title{
CHARACTERIZATION OF ACETYLCHOLINESTERASE IN INDIVIDUAL NEURONS IN THE LEECH CENTRAL NERVOUS SYSTEM $^{1}$
}

\author{
BRUCE G. WALLACE ${ }^{2}$ AND JEAN W. GILLON \\ Department of Neurobiology, Stanford University School of Medicine, Stanford, California 94305
}

Received October 5, 1981; Revised March 18, 1982; Accepted March 22, 1982

\begin{abstract}
Acetylcholinesterase (AChE) activity was measured in cholinergic and non-cholinergic neurons in the central nervous system of the leech. Intracellular AChE was assayed by pretreating intact ganglia with echothiophate to inhibit selectively extracellular enzyme. The concentration of intracellular AChE in cholinergic neurons was 3- to 24-fold higher than that in non-cholinergic cells.

The properties of $\mathrm{AChE}$ in extracts of leech ganglia were similar to those of "true" acetylcholinesterase, although butyrylthiocholine was almost as good a substrate as acetylthiocholine. There was also cholinesterase activity in leech blood; this enzyme resembled butyrylcholinesterase. Sucrose gradient velocity sedimentation of Triton X-100 extracts of leech ganglia revealed a major peak of AChE activity at $6.5 \mathrm{~S}$ and a small peak at $4.3 \mathrm{~S}$. The pattern of activity in the gradient was the same when intact ganglia were pretreated with echothiophate, although the total activity was reduced by $98 \%$.

Intact leech ganglia were stained for $\mathrm{AChE}$ activity with and without echothiophate pretreatment. In ganglia that had not been exposed to echothiophate, cholinesterase reaction product was deposited primarily on the ganglionic sheath. In pretreated ganglia, on the other hand, cholinesterase activity was concentrated within neuronal cell bodies. Electrophysiological identification and intracellular injection of the fluorescent dye Lucifer Yellow prior to staining were used to confirm that most AChE-positive cells were cholinergic motoneurons. Two previously unidentified neurons staining for $\mathrm{AChE}$ were shown to be motoneurons. These results demonstrate that cholinergic motoneurons can be differentiated from other cells in the leech nervous system by their high intracellular concentration of AChE.
\end{abstract}

A common feature of the metabolism of cholinergic neurons is the continuous synthesis and degradation of acetylcholine. Membrane-soluble inhibitors of acetylcholinesterase (AChE), the degradative enzyme, cause an increase in the level of acetylcholine $(\mathrm{ACh})$ in cholinergic nerve terminals (Birks and MacIntosh, 1961; Potter, 1970; Collier and Katz, 1971; but see Miledi et al., 1977). No increase is seen when nonpermeant inhibitors are used. These findings indicate that intracellular cholinesterase limits the accumulation of $\mathrm{ACh}$ in cholinergic neurons and suggest that such cells might be distinguished by their cholinesterase activity.

Assays of individual, identified neurons in Aplysia

\footnotetext{
'We are grateful to Domingo Aviado for his skillful technical support, Drs. John Nicholls and Denis Baylor for their helpful comments on the manuscript, and Sandy Lewis for her excellent secretarial assistance. This research was supported by United States Public Health Service Grant NS16440.

${ }^{2}$ To whom correspondence should be addressed.
}

(McCaman and Dewhurst, 1971; Giller and Schwartz, 1971b), the snail (Emson and Fonnum, 1974), and the lobster (Hildebrand et al., 1974) failed to reveal any significant difference in the level of the AChE activity in cholinergic and non-cholinergic cells. However, histochemical evidence suggests that most of the enzyme measured in those studies was associated with contaminating glial and conneclive tissue cells and not with the neurons themselves (McCaman and Dewhurst, 1971; Giller and Schwartz, 1971a, b; Hildebrand et al., 1974). Since individual cells can be isolated from leech ganglia relatively free of such contamination (Kuffler and Nicholls, 1966; Fuchs et al., 1981), we investigated the properties and distribution of cholinesterase in identified leech neurons.

Our initial aim was to compare the amount of AChE activity in cholinergic neurons with that in non-cholinergic cells. In the leech, neurons that supply excitatory innervation to body wall muscles and to the heart contain choline acetyltransferase, the enzyme that catalyzes ACh 
synthesis, suggesting that these cells release $\mathrm{ACh}$ as a transmitter (Sargent, 1977; Wallace, 1981b). One excitatory motoneuron, the large longitudinal $(\mathrm{L})$ cell, has been identified as cholinergic by several other criteria. (1) Longitudinal muscles in the leech body wall are exquisitely sensitive to $\mathrm{ACh}$; the contraction elicited by $\mathrm{ACh}$ is potentiated by eserine as is the contraction evoked by nerve stimulation (Fühner, 1917; Bacq and Coppée, 1937). (2) Intracellular recordings from longitudinal muscle fibers have shown that ACh depolarizes leech muscles (Walker et al., 1968) and that the most sensitive regions of the muscle fiber surface correspond to sites of innervation (Kuffler, 1978). (3) The excitatory synaptic potentials evoked by nerve stimulation are blocked by curare (Walker et al., 1970; Kuffler, 1978) as is the depolarizing effect of ACh (MacIntosh and Perry, 1950; Flacke and Yeoh, 1968). (4) The L motoneuron and the annulus erector motoneuron as well synthesize and accumulate $\left[{ }^{3} \mathrm{H}\right]$ acetylcholine from $\left[{ }^{3} \mathrm{H}\right]$ choline (Sargent, 1977). Thus, it seems likely that the $\mathrm{L}$ cell and all other excitatory motoneurons are cholinergic.

Relatively little information is available concerning the transmitter released by other identified neurons in the leech. One exception is the Retzius cell, which releases 5hydroxytryptamine (Lent, 1973; Mason et al., 1979; Willard, 1981). The transmitter released by mechanosensory cells and inhibitory motoneurons is not known but probably is not ACh as these cells do not contain detectable levels of choline acetyltransferase nor do they synthesize significant amounts of ACh from labeled choline (Sargent, 1977).

In the present study, in order to determine the intracellular AChE activity, intact ganglia were exposed to echothiophate, an irreversible cholinesterase inhibitor, prior to homogenization or isolation of individual cells. This phosphinylthiocholine derivative bears a net positive charge, penetrates cell membranes very slowly, and therefore selectively inhibits enzyme accessible from the extracellular space (Brimijoin et al., 1978). Cholinergic excitatory motoneurons were found to have a higher concentration of intracellular AChE than non-cholinergic Retzius, mechanosensory, and inhibitory neurons. Based on these findings, standard cholinesterase histochemical techniques were modified to demonstrate intracellular acetylcholinesterase. Cholinergic motoneurons were stained selectively by this procedure. Some of these results have been reported briefly elsewhere (Wallace, 1981a; Wallace and Gillon, 1981).

\section{Materials and Methods}

Preparation. Leeches, Hirudo medicinalis, were kept at $16^{\circ} \mathrm{C}$ in spring water. Blood was drawn by making a small incision in the body wall and puncturing a blood vessel with a fine glass pipette. Individual neurons were identified by intracellular recording and stimulation. Cells often were injected with the vital dye Fast Green to insure that the appropriate cell was isolated (Bowling et al., 1978); dye injection had no effect on the level of AChE activity. Cells were isolated by cutting the capsule, exposing the cell bodies, tying the cell soma off using 17$\mu \mathrm{m}$ nylon monofilament, and transferring the cell to the assay tube using a fine pipette (Fuchs et al., 1981).

Echothiophate pretreatment. Ganglia were dissected, rinsed with leech saline $(110 \mathrm{~mm} \mathrm{NaCl}, 4 \mathrm{~mm} \mathrm{KCl}, 7.5$ $\mathrm{mm} \mathrm{CaCl}_{2}, 10 \mathrm{~mm}$ sodium phosphate, $10 \mathrm{~mm}$ glucose, titrated to $\mathrm{pH} 7.4$ with $\mathrm{NaOH}$ ), and incubated for 15 to 30 min with $10^{-4}$ M echothiophate in saline. (The echothiophate preparation supplied by Ayerst Laboratories, Inc. also contains potassium acetate, the final concentration of which was $1.2 \mathrm{~mm}$.) After echothiophate treatment, ganglia were washed for at least $1 \mathrm{hr}$ in several changes of saline to remove unbound inhibitor and to allow inhibition to develop fully (Brimijoin et al., 1978).

Identification of motoneurons. To identify motoneurons, ganglia were dissected together with a piece of body wall. For most experiments, both the body wall and the ganglia were bathed in leech saline containing $20 \mathrm{mM}$ $\mathrm{Ca}^{2+}$, which increased the strength of evoked contractions and reduced the excitability of interneurons (Stuart, 1970). In several experiments, the saline surrounding a ganglion was isolated from that bathing the body wall with a Vaseline seal and changed to a solution containing $20 \mathrm{~mm} \mathrm{Mg}^{2+}$ to prevent activation of intraganglionic interneurons by chemical synaptic transmission. Cells that evoked contractions under these conditions were considered motoneurons.

Enzyme extracts. The central nervous system was exposed, the roots were cut near the ventral cord, and 2 to 16 ganglia, together with their connectives, were rinsed in leech saline and transferred to $50 \mu \mathrm{l}$ of ice cold $20 \mathrm{~mm}$ sodium phosphate, $\mathrm{pH} 7.0$, containing $0.5 \%$ Triton X-100 $(w / v)$ in a ground glass homogenizer. The tissue was homogenized, an additional $100 \mu \mathrm{l}$ of buffer was added, the extract was rehomogenized and centrifuged for $5 \mathrm{~min}$ at $1000 \times g$, and the supernatant fraction was diluted with buffer as necessary.

Sucrose gradient sedimentation. Velocity sedimentation analysis of $\mathrm{AChE}$ activity was performed according to the general procedure of Martin and Ames (1961). Linear sucrose gradients ( 5 to $20 \%, \mathrm{w} / \mathrm{v}$ ) were prepared in $20 \mathrm{~mm}$ sodium phosphate, $\mathrm{pH} 7.0$, containing $0.5 \%$ (w/ v) Triton $X-100$. Carbonic anhydrase (3.06 S), bacterial alkaline phosphatase $(6.1 \mathrm{~S})$, and catalase (11.3 S) were added to each sample as marker enzymes prior to sedimentation. A 75- $\mu$ l aliquot of appropriately diluted supernatant was layered onto a 4.5 -ml sucrose gradient in a cellulose nitrate tube and the samples were centrifuged in the SW 60 rotor of a Beckman model L5-75 ultracentrifuge at $4^{\circ} \mathrm{C}$. Centrifugation lasted 7 to $11 \mathrm{hr}$ at 40,000 to $50,000 \mathrm{rpm}$ so that the product $\mathrm{rpm}^{2} \cdot \mathrm{hr}$ was approximately $2 \times 10^{10}$. The gradients were fractionated by drop collection from a pinhole made in the bottom of the tube. Aliquots of each fraction were assayed for AChE (see below), carbonic anhydrase (Wilbur and Anderson, 1948), alkaline phosphatase (Garen and Levinthal, 1960), and catalase (Beers and Sizer, 1952). A graph of the meniscus and the three marker enzymes against their sedimentation constants yielded a linear relationship from which the sedimentation constant of AChE was calculated.

$A C h E$ assays. Cholinesterase activity was measured in three ways. For the characterization of enzyme in the blood and ganglion homogenates, cholinesterase activity was assayed by the method of Ellman et al. (1961). Hydrolysis of thiocholine esters was followed on a Beckman model 25 recording spectrophotometer and rates were determined from the initial slopes. When inhibitors 
were tested, enzyme was preincubated with the inhibitor for at least $5 \mathrm{~min}$; the reaction then was initiated by the addition of substrate.

AChE activity in extracts of individual cells was measured by monitoring the release of $\left[{ }^{3} \mathrm{H}\right]$ acetate from $[$ ace$\left.t y l-{ }^{3} \mathrm{H}\right]$ acetylcholine iodide (AChI). Cells were collected in $5 \mu \mathrm{l}$ of ice cold $20 \mathrm{~mm}$ sodium phosphate, $\mathrm{pH} 7.0$, containing $0.5 \%$ Triton $\mathrm{X}-100(\mathrm{w} / \mathrm{v})$. The assay was begun by the addition of $1 \mu \mathrm{l}$ of $\left[\right.$ acetyl $\left.-{ }^{3} \mathrm{H}\right] \mathrm{AChI}(49.5$ to 90 $\mathrm{mCi} / \mathrm{mmol}$, New England Nuclear) in $20 \mathrm{~mm}$ sodium phosphate $\mathrm{pH} 7.0$, and the tubes were incubated at $25^{\circ} \mathrm{C}$ for 30 to $60 \mathrm{~min}$. The concentration of $\mathrm{ACh}$ in the reaction mixture was 0.1 to $0.2 \mathrm{~mm}$. The reaction was stopped by adding $0.5 \mathrm{ml}$ of ice cold $5 \mathrm{~mm}$ sodium phosphate, $\mathrm{pH}$ 6.0 , and the contents of the tube were transferred to a 0.5 $\times 2.5 \mathrm{~cm}$ column of Bio-Rad AG 50W-X2, 100 to 200 mesh $\left(\mathrm{Na}^{+}\right.$form) cation exchange resin. The tube and column were rinsed with an additional $1.5 \mathrm{ml}$ of $\mathrm{pH} 6.0$ buffer and the effluent was collected and counted in 15 $\mathrm{ml}$ of ACS fluor (Amersham). The recovery of $\left[{ }^{3} \mathrm{H}\right]$ acetate was complete as determined by adding an excess of purified eel acetylcholinesterase (Sigma, Type VI-S). Radioaclively labeled substrate was purified by paper electrophoresis in a Durrum cell (Beckman) using $1.7 \mathrm{M}$ formate, $0.47 \mathrm{M}$ acetate, $\mathrm{pH} 2$ buffer. After electrophoresis for $1 \frac{1}{2} \mathrm{hr}$ at $430 \mathrm{~V}, \mathrm{ACh}$ was eluted with $2 \mathrm{M}$ formic acid in $90 \%$ methanol, dried, and taken up and stored at $-20^{\circ} \mathrm{C}$ in $1 \mathrm{~mm}$ formic acid in ethanol. After purification, the background per assay was approximately $330 \mathrm{dpm} / 8$ $\times 10^{4} \mathrm{dpm}$ of radioactive substrate in the reaction mixture, corresponding to $3 \mathrm{pmol} /$ assay $\cdot \mathrm{hr}$.

Sucrose gradients were assayed using a micro-modification of the method of Potter (1967) as modified by Hall (1973). Incubations were run as described above, using 5 $\mu l$ of the sucrose gradient fraction in lieu of the cell extract. The reaction was stopped with $100 \mu \mathrm{l}$ of $0.2 \mathrm{M}$ $\mathrm{HCl}$ and the contents of the assay tube were transferred to a scintillation vial containing $5 \mathrm{ml}$ of toluene:isoamyl alcohol (9:1) fluor. 'The vials were shaken vigorously and counted immediately, as the blank increased with time.

$A C h E$ histochemistry. Leech ganglia were dissected and rinsed thoroughly in saline, incubated for 15 to 30 min with saline containing $10^{-4} \mathrm{M}$ echothiophate, and then rinsed for at least $1 \mathrm{hr}$ with several changes of saline. Ganglia were transferred to ice cold 1\% formaldehyde dissolved in $0.1 \mathrm{~m}$ sodium maleate, $\mathrm{pH} 6$, and left to fix for $30 \mathrm{~min}$ at room temperature. They were rinsed with $0.1 \mathrm{~mm}$ maleate buffer and stained for AChE overnight at $4^{\circ} \mathrm{C}$ by a modification of the method of Karnovsky (1964). The incubation solution contained, in final concentration: sucrose, $175 \mathrm{~mm}$; Triton X-100, 0.5\% (w/v); sodium maleate, $32.5 \mathrm{~mm}$; sodium citrate, $5 \mathrm{~mm}$; potassium ferricyanide, $0.5 \mathrm{~mm}$; cupric sulfate, $3 \mathrm{~mm}$; acetyl thiocholine iodide, $0.1 \mathrm{mg} / \mathrm{ml}$. Incubation at $4^{\circ} \mathrm{C}$ tended to prevent background staining. Stained ganglia were rinsed briefly with buffer and then stained with water, dehydrated in ethanol, cleared in xylene, and mounted in Lustrex. Occasionally, stained ganglia were rinsed briefly with $3,3^{\prime}$-diaminobenzidine $(0.5 \mathrm{mg} / \mathrm{ml}$ in sodium maleate buffer) before dehydration to enhance the density of the cholinesterase reaction product.

Chemicals. Echothiophate (Phospholine Iodide, for ophthalmic solution, Ayerst Laboratories, Inc.) was pur- chased at a local pharmacy. Lucifer Yellow $\mathrm{CH}$ was the generous gift of Walter Stewart (Laboratory of Experimental Pathology, National Institute of Arthritis, Metabolism, and Digestive Diseases). Bacterial alkaline phosphatase (BAPF) was purchased from Worthington; catalase was from Boehringer Mannheim; carbonic anhydrase, tetraisopropylpyrophosphoramide (iso-OMPA), and 1,5-bis-(4-allyldimethylammoniumphenyl)pentan-3one dibromide (BW284c51) were from Sigma.

\section{Results}

AChE in identified cells. In an earlier study, the concentration of AChE in the large longitudinal, annulus erector, and heart excitor motoneurons was shown to be 3- to 32-fold higher than that in the non-cholinergic Retzius and mechanosensory cells (Wallace, 1981a). In order to determine if high intracellular AChE activity is a reliable indicator of cholinergic function, we have extended this analysis to include several other excitatory and inhibitory motoneurons.

Individual nerve cells were identified on the basis of the size, shape, and position of the cell body, their electrophysiological properties, and, for motoneurons, by the muscle contractions that they evoked. The cell bodies of identified neurons were isolated and 1 to 12 cells were pooled for each AChE assay.

AChE activity was present in extracts of all cells examined. For example, in ganglia exposed only to saline, the level of AChE in sensory cells was 28 to $75 \%$ of that found in the annulus erector motoneuron. When extracts of mechanosensory cells and motoneurons were mixed, the AChE activities were additive ('Table Ia). Thus, the relatively low level of activity in mechanosensory cells was not the result of some endogenous inhibitor present in excess.

TABLE I

Summation of activity in extracts

The activity, expressed as counts per min above background, is the mean of triplicate determinations; in each case the standard deviation was less than $5 \%$ of the mean. (a) The AE cell sample contained the equivalent of 2 cells; the $\mathrm{N}$ cell sample contained the equivalent of 3.75 cells. (b) The saline-pretreated extract was diluted 50 -fold before assay to yield a level of activity comparable to that in the echothiophatepretreated extract. (c) The sample from saline-pretreated ganglia contained the equivalent of $1.1 \mathrm{AE}$ cells, while the sample from echothiophate-pretreated ganglia contained $2 \Lambda \mathrm{E}$ cclls.

\begin{tabular}{lc}
\multicolumn{1}{c}{ Sample } & $\begin{array}{c}\text { Cholinesterase } \\
\text { Activity }\end{array}$ \\
\hline & $c p m$ \\
a. AE ${ }^{\text {a }}$ cell extract & 5,427 \\
N cell extract & 7,667 \\
AE cell extract + N cell extract & 12,485 \\
& \\
b. Extract of saline-pretreated ganglion & 4,086 \\
Extract of echothiophate-pretreated ganglion & 3,740 \\
Saline extract + echothiophate extract & 6,803 \\
Saline extract + 10 & 0 \\
& \\
c. AE cell extract from saline-pretreated ganglia & 3,144 \\
AE cell extract from echothiophate-pretreated & 690 \\
$\quad$ ganglia & \\
Saline extract + echothiophate extract & 3,327 \\
Saline extract $+10^{-4}$ M echothiophate & 0 \\
\hline
\end{tabular}

${ }^{a} \mathrm{AE}$, annulus erector motoneuron; $\mathrm{N}$, nociceptive cell. 
The activity associated with all cells was greatly reduced by pretreating intact ganglia with echothiophate. When extracts of ganglia or individual cells isolated after echothiophate pretreatment were mixed with extracts of saline-pretreated ganglia or cells, the AChE activity observed was $87 \%$ of that expected (Table I, b and c), indicating that inhibition by echothiophate was irreversible and little unbound inhibitor remained in the extracts. If echothiophate was added after the tissue was disrupted, however, all cholinesterase activity was inhibited (Table I, b and c). Based on these properties, it was assumed that the activity remaining after exposure of intact cells to echothiophate was located intracellularly (see "Discussion").

Consistent with earlier findings, the concentration of intracellular AChE was high in all excitatory motoneurons, while inhibitory motoneurons, Retzius, and mechanosensory cells had much lower intracellular AChE activity (Fig. 1). The data for all neurons analyzed in this way are presented in Table II. To take into account differences in soma size, cell bodies were assumed to be spherical; the average radii were determined by measuring the profiles of living cells injected with the fluorescent dye Lucifer Yellow. Intracellular AChE was calculated by correcting the echothiophate-resistant activity for differences in cell volume; surface $\mathrm{AChE}$ was determined by subtracting echothiophate-resistant AChE from the activity in saline-treated cells and expressing the difference in terms of the surface area of the soma. All cells had comparable levels of AChE associated with their surface. Motoneurons, however, had a 3- to 24fold higher concentration of intracellular $\mathrm{AChE}$ than non-cholinergic cells.

Properties of leech AChE. The cholinesterase activity of cholinergic and non-cholinergic neurons might represent different enzymes or different levels of a single enzyme. Accordingly, experiments were performed to characterize the cholinesterase activity present in ganglion and single cell extracts. The activity measured in homogenates of leech ganglia was increased by extracting with detergent; maximum activation (approximately 3fold) occurred with $0.5 \%(\mathrm{w} / \mathrm{v})$ Triton X-100. In the presence of Triton $X-100$, all of the activity remained in the supernatant after low speed centrifugation $(5 \mathrm{~min}$ at $1000 \times g$ ); only $60 \%$ of the activity remained in the supernatant in the absence of detergent. Extracting in high salt or repeated freezing and thawing decreased the activity of crude homogenates by 50 to $80 \%$ and failed to solubilize the enzyme. $\mathrm{Ca}^{2+}(0.1 \mathrm{mM}), \mathrm{Mg}^{2+}(1 \mathrm{~mm})$, and ED'TA (0.5 mM) had no effect on the level of activity in detergent extracts. The supernatant fraction from low speed centrifugation of detergent-extracted ganglion homogenates was used to characterize leech cholinesterase.

Figure 2 illustrates the dependence of cholinesterase activity in ganglion extracts on the concentration of isoOMPA, a specific inhibitor of vertebrate butyrylcholinesterase. As the concentration of iso-OMPA was increased, AChE activity gradually decreased to approxi-

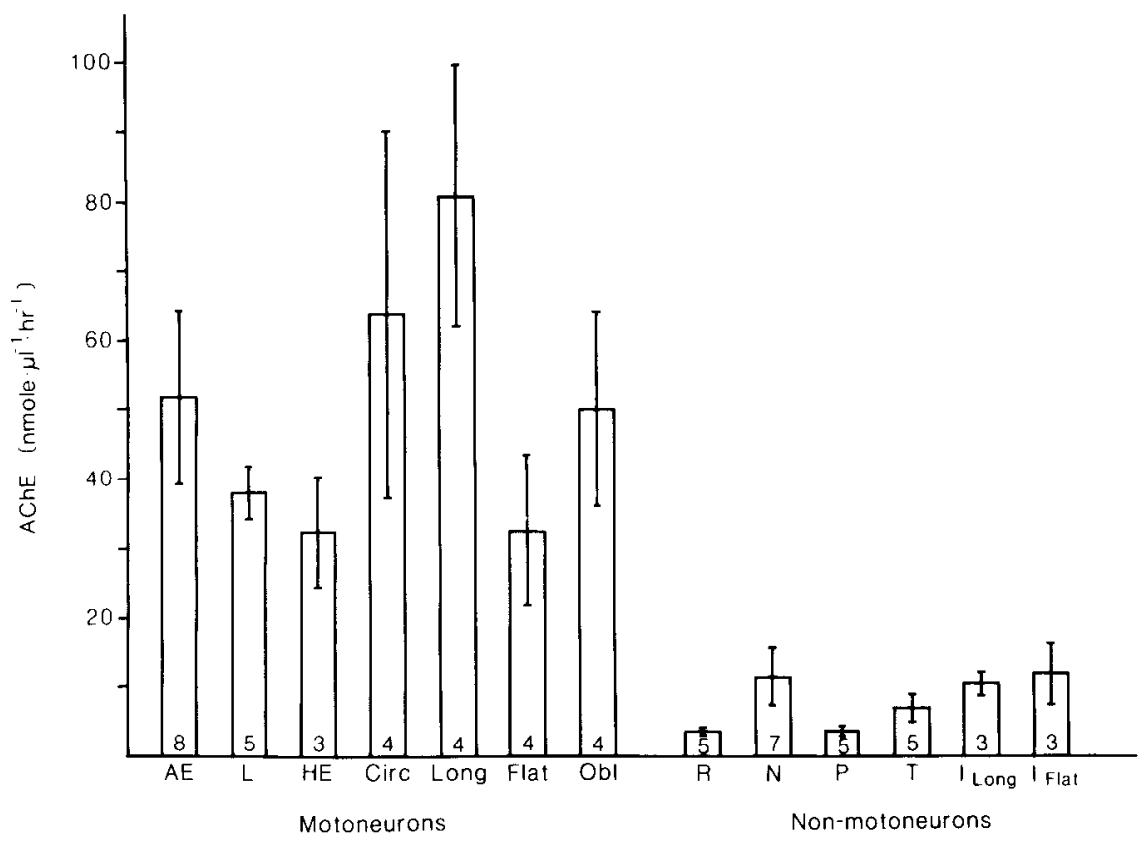

Figure 1. Concentration of intracellular AChE in identified leech neurons. AChE activity was measured after pretreatment with echothiophate and the intracellular concentration was determined using the average dimensions for each cell (see Table II). Data are expressed as the mean \pm SEM; the figure in each column gives the number of samples analyzed. Motoneurons: annulus erector (AE), large longitudinal (L), heart excitor (HE), dorsal circular (Circ, No. 112), ventromedial longitudinal (Long, No. 108), dorsoventral flattener (Flat, No. 109), and oblique (Obl, Nos. 110 and 111). Nonmotoneurons: Retzius (R), nociceptive $(\mathrm{N})$, pressure $(\mathrm{P})$ and touch $(\mathrm{T})$ mechanosensory, dorsal longitudinal inhibitor ( $\mathrm{I}_{\text {Long }}$, No. 1), and dorsoventral flattener inhibitor $\left(\mathrm{I}_{\mathrm{Flu}}\right.$, No. 101). Cells designated by number refer to the designations of Ort et al. (1974). 
TABLE II

AChE activity in identified cells

Data are expressed as the mean \pm SEM; the number of samples analyzed is given in parentheses. Cells are designated as in Figure 1 .

\begin{tabular}{|c|c|c|c|c|c|c|}
\hline \multirow{2}{*}{ Cell } & \multirow{2}{*}{ Radius } & \multicolumn{3}{|c|}{ AChE Activity } & \multirow{2}{*}{ Internal AChE } & \multirow{2}{*}{ Surface AChE } \\
\hline & & Total & & Echothiophate-resistant & & \\
\hline & $\overline{\mu m}$ & \multicolumn{3}{|c|}{$\mathrm{pmol} / \mathrm{cell} / \mathrm{hr}$} & $n m o l / \mu l / h r$ & $\mathrm{nmol} / \mathrm{mm}^{2} / \mathrm{hr}$ \\
\hline \multicolumn{7}{|c|}{ Motoneurons } \\
\hline $\mathrm{AE}$ & 28.9 & $47.88 \pm 7.55$ & (8) & $5.23 \pm 1.25(8)$ & 51.7 & 4.06 \\
\hline $\mathrm{L}$ & 24.6 & $44.06 \pm 2.63$ & (4) & $2.37 \pm 0.24(5)$ & 38.0 & 5.48 \\
\hline $\mathrm{HE}$ & 20.6 & $21.43 \pm 1.98$ & (4) & $1.18 \pm 0.29(3)$ & 32.2 & 3.80 \\
\hline Circ & 22.3 & $24.00 \pm 6.20$ & (4) & $2.95 \pm 1.23(4)$ & 63.5 & 3.36 \\
\hline Long & 24.7 & $43.72 \pm 9.20$ & (4) & $5.11 \pm 1.19$ & 80.6 & 5.02 \\
\hline Flat & 25.2 & $35.80 \pm 9.21$ & (4) & $2.18 \pm 0.73(4)$ & 32.4 & 4.21 \\
\hline Obl & 22.4 & $39.08 \pm 16.34$ & (4) & $2.34 \pm 0.65(4)$ & 49.7 & 5.83 \\
\hline \multicolumn{7}{|c|}{ Nonmotoneurons } \\
\hline $\mathbf{R}$ & 42.7 & $72.72 \pm 9.65$ & (5) & $1.15 \pm 0.11(5)$ & 3.53 & 3.12 \\
\hline $\mathbf{N}$ & 24.4 & $16.06 \pm 3.74$ & $(8)$ & $0.68 \pm 0.27(7)$ & 11.16 & 2.05 \\
\hline $\mathbf{P}$ & 31.3 & $34.52 \pm 2.02$ & (6) & $0.44 \pm 0.08(5)$ & 3.43 & 2.77 \\
\hline $\mathrm{T}$ & 24.9 & $12.56 \pm 2.93$ & $(6)$ & $0.44 \pm 0.13(5)$ & 6.81 & 1.56 \\
\hline$I_{\text {Lang }}$ & 20.7 & $11.60 \pm 4.58$ & (3) & $0.38 \pm 0.06(3)$ & 10.32 & 2.08 \\
\hline$I_{\text {Flat }}$ & 24.6 & $16.44 \pm 6.52$ & $(3)$ & $0.73 \pm 0.27(3)$ & 11.74 & 2.07 \\
\hline
\end{tabular}

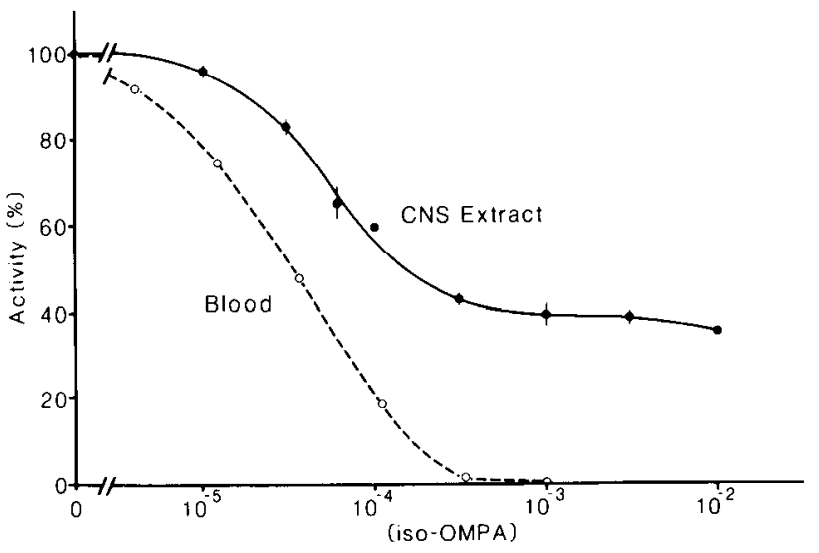

Figure 2. Inhibition of leech cholinesterase by iso-OMPA. Samples were preincubated and assayed with iso-OMPA at the concentrations indicated. The results are expressed as the percentage of activity in the absence of inhibitor. $0.5 \%$ Triton X-100 extract of ventral nerve cord assayed in triplicate with $1 \mathrm{~mm}$ acetylthiocholine as substrate. Error bars, shown where they exceed the size of the point, are $\pm \mathrm{SD}$. $\mathrm{O}_{---O}$, Blood diluted with $0.5 \%$ Triton $\mathrm{X}-100$ and assayed with $1 \mathrm{mM}$ butyrylthiocholine as substrate.

mately $40 \%$ of the uninhibited level. The shape of the curve suggests that extracts of the leech central nervous system have two forms of cholinesterase, one sensitive to inhibition by iso-OMPA $\left(\mathrm{I}_{50} \simeq 5 \times 10^{-5} \mathrm{M}\right)$ and a second not affected by the inhibitor. Although the dependence of AChE activity on iso-OMPA concentration was similar from extract to extract, the level of the plateau (i.e., the fraction of cholinesterase activity not inhibited by isoOMPA) varied from 30 to $70 \%$.

Leech blood also contained cholinesterase activity. Blood cholinesterase was inhibited completely by isoOMPA; the shape of the curve was consistent with a single enzyme species (Fig. 2). The dependence of blood cholinesterase activity on iso-OMPA concentration ( $I_{50}$ $\left.\simeq 3 \times 10^{-5} \mathrm{M}\right)$ was similar to that of the inhibitable portion of the activity in ganglion extracts, suggesting that blood may not have been rinsed completely from the ganglia during dissection. Blood cholinesterase also was inhibited completely by BW284c 51 at $10^{-5} \mathrm{M}$ and by echothiophate at $10^{-6} \mathrm{M}$. Leech blood cholinesterase hydrolyzed both butyryl- and acetylthiocholine. Although the maximum velocities with the two substrates were comparable, the apparent affinity of blood cholinesterase was much greater for butyrylthiocholine $\left(K_{M}\right.$, app $=13$ $\mu \mathrm{M})$ than for acetylthiocholine $\left(K_{M \text {, app }}=0.79 \mathrm{mM}\right)$. Thus, the cholinesterase activity in leech blood resembles vertebrate butyrylcholinesterase.

In order to determine the kinetic properties of the second cholinesterase activity in ganglion extracts, measurements were made in the presence of $10^{-3} \mathrm{M}$ iso-OMPA, a concentration that completely inhibited leech butyrylcholinesterase. Under these conditions, ganglion extracts hydrolyzed both thiocholine esters (Fig. 3). The affinities for the two substrates were comparable (butyrylthiocholine, $K_{M \text {, app }}=50 \mu \mathrm{M}$; acetylthiocholine, $K_{M}$, app $=17$ $\mu \mathrm{M})$, but the maximum velocity was approximately 7 -fold higher with acetylthiocholine as a substrate. The affinity for acetylcholine, determined using the radiochemical assay, was $K_{M \text {, app }}=14.8 \pm 1.30 \mu \mathrm{M}$ (mean $\pm \mathrm{SEM} ; N=$ $3)$. The iso-OMPA-insensitive cholinesterase activity was inhibited by BW284c51 (50\% at $\left.2 \times 10^{-8} \mathrm{M}\right)$. With acetylcholine, there was some evidence for substrate inhibition at concentrations above $0.2 \mathrm{mM}$; the same was true with butyrylthiocholine. With acetylthiocholine, substrate inhibition was not apparent until concentrations above $1 \mathrm{mM}$ were used; at $10 \mathrm{~mm}$, activity was reduced by approximately $40 \%$. These properties identify this activity as an acetylcholinesterase, although with somewhat less substrate specificity than vertebrate $\mathrm{AChE}$.

Although it seemed likely that the butyrylcholinesterase present in ganglion extracts was from blood or glial cells, inhibition by iso-OMPA was used to examine whether a butyrylcholinesterase was associated with cholinergic or non-cholinergic neurons or if either surface or intracellular cholinesterase was butyrylcholinesterase. Extracts of identified cells isolated with or without ex- 


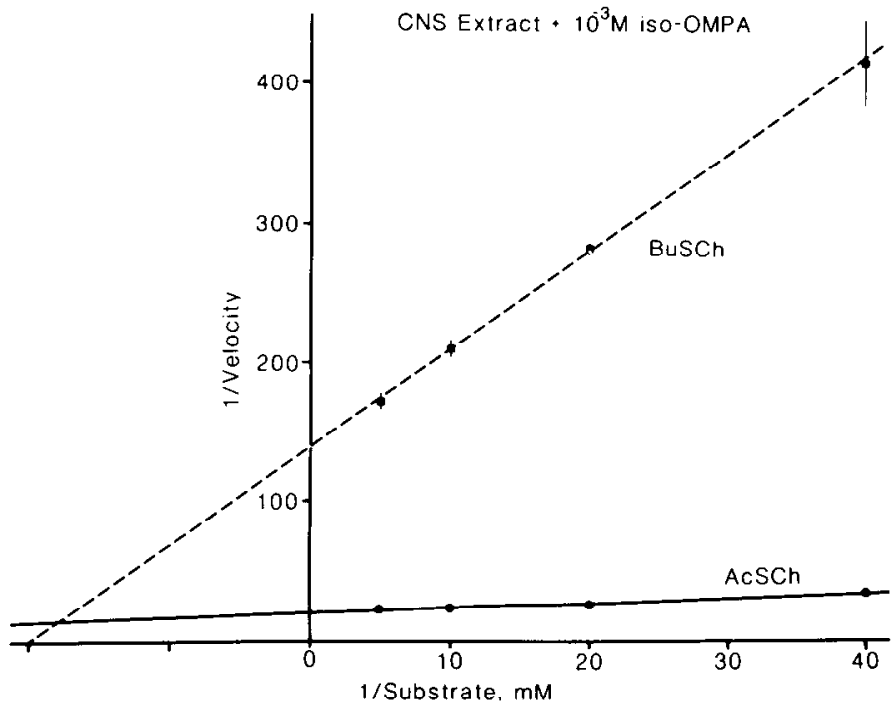

Figure 3. Kinetics of hydrolysis by CNS extract. A detergent extract of ventral nerve cord was preincubated with $10^{-3} \mathrm{M}$ isoOMPA. Lineweaver-Burke plots are shown for acetylthiocholine (AcSCh, - and butyrylthiocholine (BuSCh, - - - ) as substrates. The lines drawn by linear regression give apparent $K_{m}$ values of $17 \mu \mathrm{M}$ for acetylthiocholine and 50 $\mu_{\mathrm{M}}$ for butyrylthiocholine. The results are expressed as the mean of duplicate determinations; the range is shown where it exceeds the size of the data point.

posure to echothiophate were assayed in the presence and absence of $10^{-3} \mathrm{M}$ iso-OMPA. None of the samples was inhibited; the ratio (mean \pm SEM) of activity measured in the presence of iso-OMPA to that in controls was $1.02 \pm 0.05(N=5)$ for non-cholinergic cells and $1.11 \pm$ $0.08(N=3)$ for cholinergic cells. The corresponding ratios for cells pretreated with echothiophate were 1.13 $\pm 0.12(N=3)$ for non-cholinergic and $1.24(N=1)$ for cholinergic neurons. Thus, all of the cholinesterase associated with isolated cells, both intracellular and surface activity, is true acetylcholinesterase.

Molecular form of AChE. Several species of AChE have been identified in extracts of vertebrate muscle by sucrose gradient velocity sedimentation (Hall, 1973; Bon et al., 1979; Massoulié et al., 1980). When detergent extracts of leech ganglia were analyzed by sucrose gradient velocity sedimentation, AChE activity ran as a single major peak with an average sedimentation constant of $6.5 \pm 0.04 \mathrm{~S}$ (mean $\pm \mathrm{SEM} ; N=3$ ) (Fig. $4 a$ ). There was also a small peak at $4.3 \pm 0.09 \mathrm{~S}$ (mean \pm SEM; $N=3$ ), accounting for approximately $10 \%$ of the total activity. If ganglia were pretreated with echothiophate and then extracted, total AChE activity was reduced by approximately $98 \%$. The residual, originally intracellular, $\mathrm{AChE}$ had the same pattern of activity on sucrose gradient sedimentation (Fig. $4 b$ ), suggesting that there was no obvious difference in the molecular properties between surface and intracellular $\mathrm{AChE}$.

Ganglia also were extracted with detergent containing $1 \mathrm{M} \mathrm{NaCl}$ with or without $1 \mathrm{~mm}$ EGTA. High salt inhibited AChE activity in ganglion extracts by approximately $20 \%$. Under these conditions, leech AChE ran as a single peak on sucrose gradient velocity sedimentation with a mean sedimentation coefficient of $5.8 \pm 0.04$ (mean \pm SEM; $N=5$ ). No difference in the pattern of activity on gradients containing $1 \mathrm{M} \mathrm{NaCl}$ was observed when ganglia were pretreated with echothiophate.

$A C h E$ histochemistry. Ganglia were dissected, treated with echothiophate to inhibit extracellular AChE, rinsed, fixed, and stained for $\mathrm{AChE}$ in the presence of detergent in order to facilitate penetration of the reagents into the cells. A photograph of the dorsal surface of a ganglion stained in this way is shown in Figure 5a. Only about $30 \%$ of the neurons present on the dorsal surface of the ganglion stained for cholinesterase. The pattern of stained cells corresponds to the distribution of identified motoneurons (Stuart, 1970; Ort et al., 1974). Several experiments were done to determine if the accumulation of reaction product was due to $\mathrm{AChE}$ activity. Only light background staining was observed if eserine, echothiophate, or BW284c51 was included in the staining solution (Fig. 5c). On the other hand, the intensity and distribution of reaction product were unchanged when ganglia were stained in the presence of iso-OMPA (Fig. $5 b$ ). These results indicate that the reaction product was due to AChE activity. Two pairs of small laterally located cells consistently showed an accumulation of reaction product in the presence of AChE inhibitors (see Fig. 5c). The stain in these cells thus was not likely to be due to cholinesterase activity and was not investigated further. Ganglia not pretreated with echothiophate were stained intensely, consistent with the biochemical finding that the level of $\mathrm{AChE}$ activity in ganglion extracts was re-
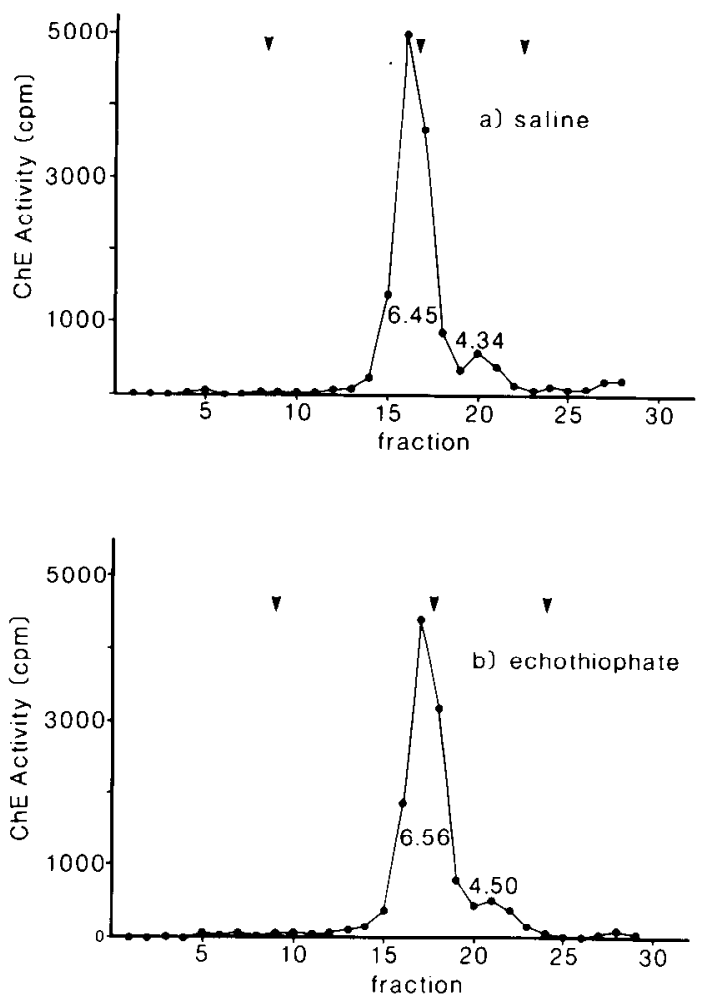

Figure 4. Sucrose density gradient velocity sedimentation of CNS extracts. The markers, from left to right, are catalase (11.3 S), bacterial alkaline phosphatase $(6.1 \mathrm{~S})$, and carbonic anhydrase $(3.06 \mathrm{~S})$; the final fraction to the right represents the top of the gradient. $a$, Saline: ganglia incubated in saline before extraction. The sample contained the equivalent of 0.4 ganglion. $b$, Echothiophate: ganglion pretreated with echothiophate before extraction. The sample contained the equivalent of 5.2 ganglia. 

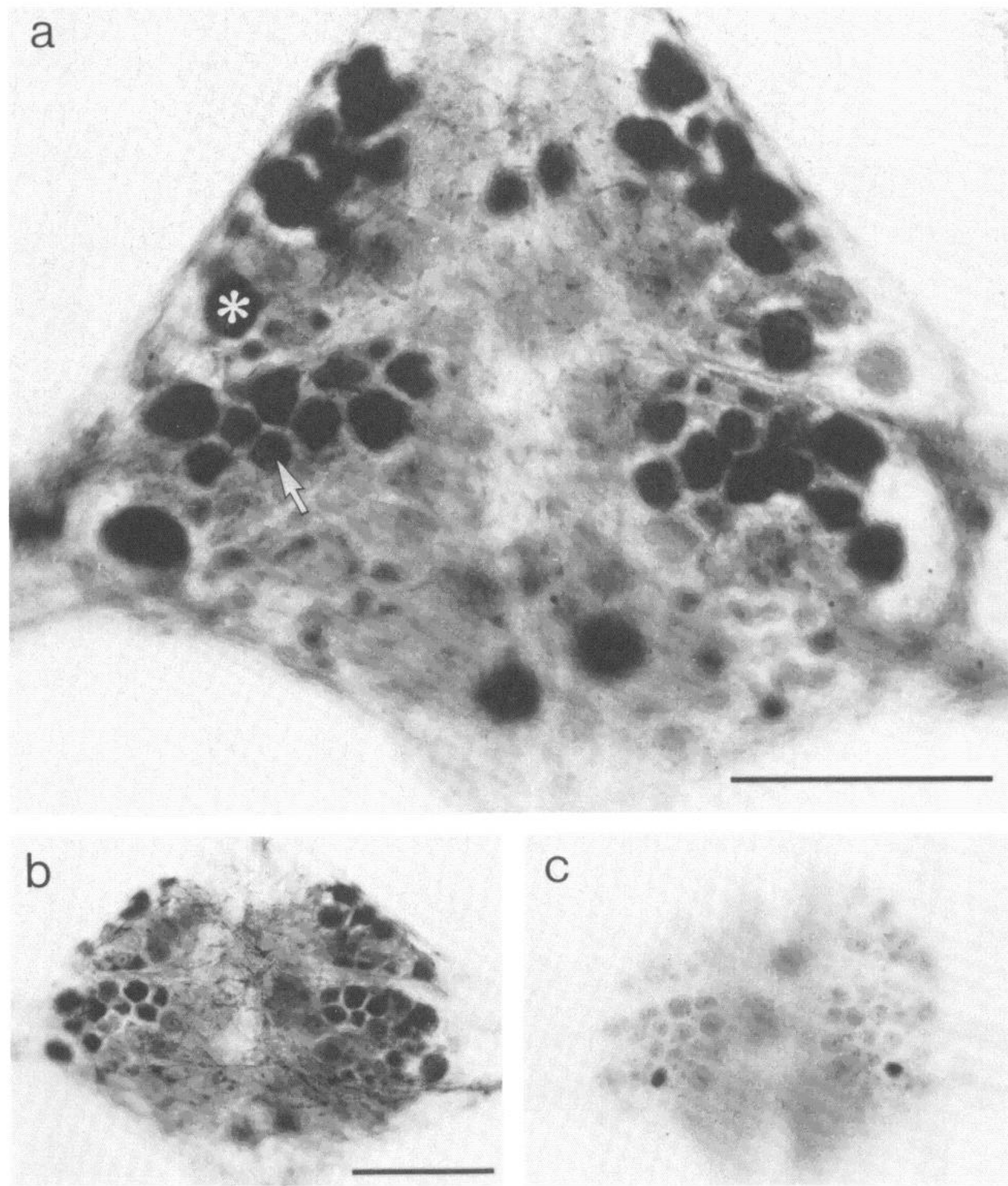

Figure 5. Histochemical demonstration of intracellular AChE. a, Light micrograph showing the dorsal surface of a whole mount of a ganglion treated with echothiophate, fixed, and stained for cholinesterase (see "Materials and Methods"). Dark granular reaction product is seen in approximately $30 \%$ of the neuronal somata. Two of the stained cells were found to be previously unidentified motoneurons, one innervating flattener muscles (asterisk) and the other innervating dorsolateral longitudinal muscles (arrow). $b$, As in $a$ but iso-OMPA $\left(10^{-3} \mathrm{M}\right)$ was included during staining. $c$, As in $a$ but eserine (10 $0^{-4}$ ) was included during staining; BW284c51 $\left(10^{-5} \mathrm{M}\right)$ and echothiophate $\left(10^{-4} \mathrm{M}\right)$ gave similar results. $\mathrm{Bar}, 200 \mu \mathrm{m}$.

duced $98 \%$ by pretreatment with echothiophate. Without echothiophate pretreatment, most of the reaction product was deposited near the surface of the ganglion, suggesting that cholinesterase activity was so concentrated in the ganglionic sheath that the reagents failed to penetrate. Experiments on frozen sections of ganglia not treated with echothiophate demonstrated intense staining of the neuropil. If detergent was not included in the 
incubation mixture, staining of intact ganglia was light and occurred primarily on the ganglionic sheath. Triton $\mathrm{X}-100$ could be replaced with saponin; dimethyl sulfoxide was not effective. By using Nomarski differential interference contrast optics to make optical sections through ganglion whole mounts, it was clear that the granular reaction product was deposited in the cytoplasm of stained cells (see Fig. 6). Thus, the quantitative difference in the concentration of intracellular AChE between cholinergic and non-cholinergic neurons was large enough to be demonstrable histochemically.

Identification of stained cells. Although the size and position of cells in leech ganglia are relatively constant, intracellular recording and stimulation are often necessary to identify neurons unambiguously. Therefore ganglia were dissected together with a piece of body wall and motoneurons were impaled, stimulated to evoke muscle contractions, and marked by intracellular injection of Lucifer Yellow (Stewart, 1978). The ganglia then were treated with echothiophate and processed for AChE histochemistry. As illustrated in Figure 6, reaction product accumulated in all identified motoneurons. Known noncholinergic cells, such as mechanosensory cells, Retzius cells, and neurons that supply inhibitory innervation to body wall muscles did not stain. Staining also was seen occasionally in "micro glia" (Coggeshall and Fawcett, 1964) and other small cells in the ganglionic capsule. In motoneurons, the reaction product had a granular appearance and usually was not found immediately adjacent to the cell membrane. This distribution was most obvious in Lucifier Yellow-injected cells or when ganglia were observed with Nomarski optics, which revealed a 2 to $6-\mu \mathrm{m}$ rim of cytoplasm between the plasma membrane of the cell and the AChE reaction product.

In addition to known motoneurons, several other cells consistently stained for intracellular AChE. Intracellular stimulation of two of these cells evoked contraction of muscles in the body wall. This response persisted when the solution bathing the ganglion contained $20 \mathrm{~mm} \mathrm{Mg} \mathrm{Mg}^{2+}$, indicating that these cells were probably motoneurons. One of these cells was located in a cluster of motoneurons on the dorsal surface of each hemiganglion and innervated longitudinal muscles in the dorsolateral portion of the contralateral body wall (see Fig. $5 a$, arrow). The other cell also was located on the dorsal side of the ganglion in the anterolateral packet and just anterior to the large longitudinal motoneuron (see Fig. $5 a$, asterisk). This neuron innervated dorsoventral flattener muscles located in the medial portion of the ipsilateral body wall. One other neuron that stained for intracellular AChE
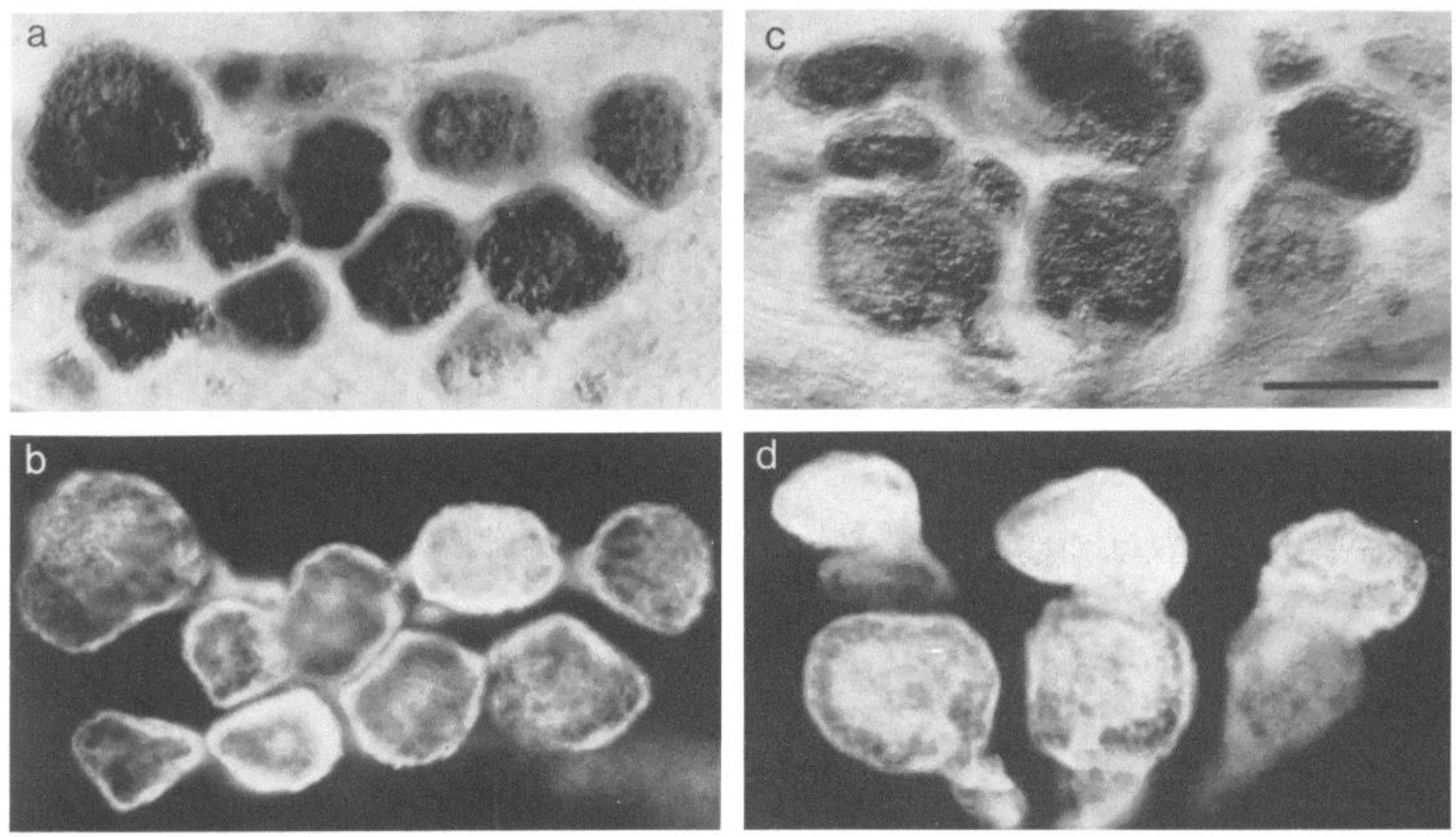

Figure 6. Identification of cells staining for intracellular AChE. Physiologically identified excitatory motoneurons were injected with Lucifer Yellow; then the ganglion was treated with echothiophate, fixed, and stained for intracellular AChE. Whole mounts were photographed with transmitted light and Nomarski optics to visualize AChE reaction product $(a$ and $c)$ and with fluorescent optics to identify cells injected with Lucifer Yellow $(b$ and $d)$. Each of the identified motoneurons stained for intracellular AChE. Bar, $50 \mu \mathrm{m}$. $a$ and $b$, Dorsal surface of a ganglion in which the L cell and motoneurons $3,4,5,7,8,11,12$, and 17 (see Ort et al., 1974) were identified and marked with Lucifer Yellow. The midline is to the right; anterior is to the top of the figure. $c$ and $d$, Anterolateral edge of a ganglion in which excitatory motoneurons 106 to 112 (see Ort et al., 1974) were injected with Lucifer Yellow. Anterior is to the left. In similar experiments (not shown), identified AE, HE, and circular (cell v2; see Stuart, 1970) motoneurons stained for intracellular AChE. 
was the Leydig cell. Although the function of this neuron is unknown, stimulation of Leydig cells does not cause any noticeable contraction of body wall muscles.

\section{Discussion}

Properties of leech cholinesterases. The high affinity for acetylcholine, susceptibility to substrate inhibition, and sensitivity to inhibition by BW284c51, but not isoOMPA, identify one of the cholinesterases in leech ganglia as a true acetylcholinesterase. It resembles that found in other invertebrates in which the cellular distribution of AChE has been measured, although the estimated $K_{M}$ for acetylthiocholine of leech AChE $(17 \mu \mathrm{M})$ is significantly lower than that of AChE in Helix ( $0.25 \mathrm{~mm})$, Aplysia (0.22 mM), or Homarus (0.25 mM) (Emson and Kerkut, 1971; Emson and Fonnum, 1974; Giller and Schwartz, 1971b; Hildebrand et al., 1974).

The physical properties of leech AChE are different from properties of $\mathrm{AChE}$ from many other species that have been examined in that it runs as a single peak at 5.8 $\mathrm{S}$ on velocity sedimentation through sucrose gradients containing Triton X-100 and $1 \mathrm{~m} \mathrm{NaCl}$. In the absence of $1 \mathrm{~m} \mathrm{NaCl}$, a slight heterogeneity was observed, with the major peak running at $6.5 \mathrm{~S}$ and a secondary peak running at $4.3 \mathrm{~S}$. These properties are similar to those of lobster AChE, which has a major peak at $7.1 \mathrm{~S}$ and a minor peak at $5.1 \mathrm{~S}$ in the absence of detergent and runs as a single peak of $6.4 \mathrm{~S}$ in the presence of Triton X-100 (Hildebrand et al., 1974). The lack of heterogeneity of AChE in the leech suggests that intracellular enzyme differs little in its physical characteristics from enzyme found associated with neuronal and glial membranes or enzyme concentrated extracellularly in the neuropil.

The cholinesterase in leech blood, on the other hand, resembles vertebrate butyrylcholinesterase in its substrate specificity and inhibition by iso-OMPA. The blood of Aplysia and Helix also has high levels of cholinesterase activity. However, the enzyme in molluscan blood has the characteristics of acetylcholinesterase (Augustinsson, 1963; Giller and Schwartz, 1971b; Bevelaqua et al., 1975).

Measurement of intracellular AChE concentration. The estimates of intracellular AChE concentration were based on the assumption that exposing intact ganglia to echothiophate selectively and completely inhibited extracellular enzyme (see Brimijoin et al., 1978). This assumption is supported by two biochemical findings. First, the activity in mixtures of extracts of untreated and echothiophate-pretreated ganglia was additive, indicating that inhibition was irreversible and that unbound inhibitor was washed out of the ganglia before they were homogenized. Second, the concentration of echothiophate used to pretreat ganglia $\left(10^{-4} \mathrm{M}\right)$ was two orders of magnitude greater than that necessary to inhibit completely cholinesterase activity in ganglion extracts. Several histochemical observations are also consistent with the hypothesis that echothiophate-resistant AChE represents intracellular enzyme. In the presence of eserine or echothiophate, no reaction product accumulated, indicating that the procedure was detecting cholinesterase activity. In the absence of echothiophate pretreatment, dense reaction product accumulated near the surface of the ganglion, making the whole mount opaque. Staining frozen sections revealed that the neuropil was the most reactive region in ganglia not exposed to echothiophate, as has been reported previously (Silver, 1974). After echothiophate pretreatment, staining was observed primarily within cell somata; some staining of the capsule, connectives, and roots occurred. Little or no staining took place in the absence of detergent, suggesting that, even after fixation, the neuronal and glial membranes offer significant barriers for the diffusion of at least one component of the histochemical reaction mixture. Thus, although it is possible that there are forms of cholinesterase in leech ganglia that differ in their sensitivity to echothiophate, the biochemical and histochemical data strongly support the assumption that echothiophate-resistant activity represents intracellular AChE, enzyme that was inaccessible when this positively charged inhibitor was applied to intact ganglia.

Intracellular AChE in cholinergic and non-cholinergic neurons. The biochemical results reported in this paper indicate that neurons in the central nervous system of the leech can be distinguished from one another by their concentration of intracellular AChE. Cholinergic excitatory motoneurons had approximately 10-fold higher intracellular AChE activity than non-cholinergic Retzius cells, mechanosensory cells, or inhibitory motoneurons. The high level of $\mathrm{AChE}$ in motoneurons could be demonstrated histochemically using echothiophate pretreatment to inhibit extracellular AChE. All neurons in leech ganglia that provide excitatory input to peripheral musculature stained for intracellular cholinesterase. Recent observations on the distribution of choline acetyltransferase in leech neurons suggests that two other cells, the "anterior pagoda" and the "nut," contain levels of choline acetyltransferase comparable to those found in motoneurons and therefore may release $\mathrm{ACh}$ as a transmitter (Wallace, 1981b). These cells, whose function is not known, did not stain for intracellular AChE. One other cell of unknown function, the Leydig cell, consistently stained for intracellular AChE but does not contain detectable choline acetyltransferase activity (Wallace, 1981b). Thus, although all cholinergic excitatory motoneurons in leech ganglia had a high concentration of intracellular AChE, high intracellular AChE activity is not necessary or sufficient evidence to identify a cell as cholinergic.

Since AChE is known to be especially concentrated at cholinergic synapses, cholinoceptive cells might be expected to have high levels of AChE. Nearly all leech neurons respond to iontophoretic application of $\mathrm{ACh}$ to their cell bodies (Sargent et al., 1977). Some cells that respond to $\mathrm{ACh}$, such as the mechanosensory neurons, did not stain for intracellular AChE. It is not known, however, which cells in leech ganglia receive cholinergic synaptic input.

Role of intracellular AChE. The high level of intracellular AChE in leech motoneurons is consistent with the role that degradation plays in limiting the accumulation of ACh in cholinergic neurons (Collier and Katz, 1971). In cat sympathetic ganglia and rat diaphragm, the initial rate of ACh accumulation following AChE inhibition suggests that, at rest, a nerve terminal synthesizes and degrades an amount of ACh equal to its initial stores every 20 min (Birks and MacIntosh, 1961; Potter, 1970). Although comparable measurements have not been made 
in leech ganglia, the amount of labeled ACh synthesized and accumulated by motoneurons incubated with tritiated choline is increased approximately 4 -fold in the presence of eserine, indicating that $\mathrm{AChE}$ is active within cholinergic neurons in the leech as well (Sargent, 1977). The rapid turnover of $\mathrm{ACh}$ within cholinergic neurons suggests that $\mathrm{ACh}$ accumulation could be regulated directly by the activities of the synthetic and degradative enzymes, in a manner analogous to that proposed for $\gamma$ aminobutyric acid in efferent inhibitory neurons in the lobster (Hall et al., 1970). Extracts of annulus erector motoneurons can synthesize approximately $2.3 \mathrm{pmol}$ of $\mathrm{ACh} /$ cell.hr at $23^{\circ} \mathrm{C}$ (Sargent, 1977). The intracellular AChE activity in annulus erector motoneurons is 5.4 $\mathrm{pmol} / \mathrm{cell} \cdot \mathrm{hr}$ at $25^{\circ} \mathrm{C}$. The similarity in the level of activity of the synthetic and degradative enzymes makes it seem feasible that ACh could accumulate to a steady state at which synthesis and degradation were equal. However, even in the presence of eserine, intact annulus erector motoneurons appear to synthesize and accumulate only about $7 \mathrm{fmol}$ of $\mathrm{ACh} /$ cell $\cdot \mathrm{hr}$ when incubated with labeled choline (Sargent, 1977). Unless $99.7 \%$ of the ACh synthesized in leech motoneurons is released immediately or transported into the neuropil, it would appear that choline acetyltransferase activity in situ is two orders of magnitude lower than that found in extracts. Although the same could be true of AChE activity, it seems likely that AChE is present in excess intracellularly and that the level to which $\mathrm{ACh}$ accumulates must be determined, at least in part, by additional factors. Experiments in Aplysia suggest that one such factor is the uptake of choline and its concentration in the intracellular pool that is available for acetylation (Eisenstadt and Schwartz, 1975).

AChE as a cholinergic marker. There seems to be general agreement that, under appropriate conditions, AChE staining selectively reveals cholinergic neurons in cryostat sections of cat sympathetic ganglia (Robinson, 1971; Silver, 1974; Lundberg et al., 1979). However, AChE staining can occur in non-cholinergic cells, such as adrenergic sympathetic neurons in the rat and sensory neurons in amphibians, reptiles, birds, and mammals (see Silver, 1974; Lundberg et al., 1979). In such studies on frozen sections of complex tissues, it is often difficult to compare the intensity of staining in known cholinergic and noncholinergic cells or, in some cases, to distinguish hetween extracellular and intracellular activity. In leech ganglia, where individual identified neurons can be compared, high levels of intracellular AChE were found in all cholinergic motoneurons. Cholinesterase-rich neurons could be demonstrated histochemically in ganglion whole mounts, which led to the identification of two new motoneurons in the leech central nervous system. Thus, although high intracellular $\mathrm{AChE}$ is not an unambiguous marker for cholinergic cells, histochemical demonstration of echothiophate-resistant AChE, especially in intact tissues, can be a useful method for revealing presumptive cholinergic neurons.

\section{References}

Augustinsson, K. -B. (1963) Classification and comparative enzymology of the cholinesterases and methods for their determination. In Handbach der Experimentellen Pharma- kologie $X V$, G. B. Koelle, ed., pp. 89-128, Springer-Verlag, Berlin.

Bacq, Z. M., and G. Coppée (1973) Action de l'ésérine sur la préparation neuromusculaire du siponcle et de la sangsue. C. R. Soc. Biol. (Paris) 124: 1244-1247.

Beers, R. F., Jr., and I. W. Sizer (1952) A spectrophotometric method for measuring the breakdown of hydrogen peroxide by catalase. J. Biol. Chem. 195: 133-140.

Bevelaqua, F. A., K. S. Kim, M. H. Kumarasiri, and J. H. Schwartz (1975) Isolation and characterization of acetylcholinesterase and other particulate proteins in the haemolymph of Aplysia californica. J. Biol. Chem. 250: 731-738.

Birks, R., and F. C. MacIntosh (1961) Acetylcholine metabolism of a sympathetic ganglion. Can. J. Biochem. Physiol. 39: 787827.

Bon, S., M. Vigny, and J. Massoulié (1979) Asymmetric and globular forms of acetylcholinesterase in mammals and birds. Proc. Natl. Acad. Sci. U. S. A. 76: 2546-2550.

Bowling, D., J. G. Nicholls, and I. Parnas (1978) Destruction of a single cell in the central nervous system of the leech as a means of analyzing its connexions and functional role. J. Physiol. (Lond.) 282: 169-180.

Brimijoin, S., K. Skau, and M. J. Wiermaa (1978) On the origin and fate of external acetylcholinesterase in peripheral nerve. J. Physiol. (Lond.) 285: 143-158.

Coggeshall, R. E., and D. W. Fawcett (1964) The fine structure of the central nervous system of the leech, Hirudo medicinalis. J. Neurophysiol. 27: 229-289.

Collier, B., and H. S. Katz (1971) The synthesis, turnover and release of surplus acetylcholine in a sympathetic ganglion. $J$. Physiol. (Lond.) 214: 537-552.

Eisenstadt, M. L., and J. H. Schwartz (1975) Metabolism of acetylcholine in the nervous system of Aplysia californica. III. Studies of an identified cholinergic neuron. J. Gen. Physiol. 65: 293-313.

Ellman, G. L., K. D. Courtney, V. Andres, Jr., and R. M. Featherstone (1961) A new and rapid colourimetric determination of acetylcholineserase activity. Biochem. Pharmacol. 7: 88-95.

Emson, P. C., and F. Fonnum (1974) Choline acetyltransferase, acetylcholinesterase and aromatic L-amino acid decarboxylase in single identified nerve cell bodies from snail Helix aspersa. J. Neurochem. 22: 1079-1088.

Emson, P. C., and G. A. Kerkut (1971) Acetylcholinesterase in snail brain. Comp. Biochem. Physiol. (B) 39: 879-889.

Flacke, W., and T. S. Yeoh (1968) The action of some cholinergic antagonists and anticholinesterase agents on the dorsal muscle of the leech. Br. J. Pharmacol. Chemother. 33: 145153.

Fuchs, P. A., J. G. Nicholls, and D. F. Ready (1981) Membrane properties and selective connexions of identified leech neurons in culture. J. Physiol. (Lond.) 316: 203-223.

Fühner, J. (1917) Ein Vorlesungsversuch zur Demonstration der erregbarkeitssteigernden Wirkung des Physostigmins. Arch. Exp. Pathol. Pharmakol. 82: 81-85.

Garen, A., and C. Levinthal (1960) A fine-structure genetic and chemical study of the enzyme alkaline phosphatase of $E$. coli. I. Purification and characterization of alkaline phosphatase. Biochim. Biophys. Acta 38: 470-483.

Giller, E., Jr, and J. H. Schwartz (1971a) Choline acetyltransferase in identified neurons of abdominal ganglion of Aplysia californica. J. Neurophysiol. 34: 93-107.

Giller, E., Jr., and J. H. Schwartz (1971b) Acetylcholinesterase in identified neurons of abdominal ganglion of Aplysia californica. J. Neurophysiol. 34: 108-115.

Hall, Z. W. (1973) Multiple forms of acetylcholinesterase and their distribution in endplate and non-endplate regions of rat diaphragm muscle. J. Neurobiol. 4: 343-361.

Hall, Z. W., M. D. Bownds, and E. A. Kravitz (1970) The 
metabolism of gamma aminobutyric acid in the lobster nervous system. Enzymes in single excitatory and inhibitory axons. J. Cell Biol. 46: 290-299.

Hildebrand, J. G., J. G. Townsel, and E. A. Kravitz (1974) Distribution of acetylcholine, choline, choline acetyltransferase and acetylcholinesterase in regions and single identified axons of the lobster nervous system. J. Neurochem. 23: 951963.

Karnovsky, M. J. (1964) The localization of cholinesterase activity in rat cardiac muscle by electron microscopy. J. Cell Biol. 23: 217-232.

Kuffler, D. P. (1978) Neuromuscular transmission in longitudinal muscle of the leech, Hirudo medicinalis. J. Comp. Physiol. 124: 333-338.

Kuffler, S. W., and J. G. Nicholls (1966) The physiology of neuroglial cells. Ergeb. Physiol. Biol. Chem. Exp. Pharmakol. 57: $1-90$.

Lent, C. M. (1973) Retzius cells: Neuroeffectors controlling mucus release by the leech. Science 179: 693-696.

Lundberg, J. M., T. Hökfelt, M. Schultzberg, K. Uvnäs-Wallensten, C. Köhler, and S. I. Said (1979) Occurrence of vasoactive intestinal polypeptide (VIP)-like immunoreactivity in certain cholinergic neurons of the cat: Evidence from combined immunohistochemistry and acetylcholinesterase staining. Neuroscience 4: 1539-1559.

MacIntosh, F. C., and W. L. M. Perry (1950) Biological estimation of ACh. In Methods in Medical Research, R. W. Gerard, ed., pp. 78-92, Year Book, Chicago.

Martin, R. G., and B. N. Ames (1961) A method for determining the sedimentation behavior of enzymes: Application to protein mixtures. J. Biol. Chem. 236: 1372-1379.

Mason, A., A. J. Sunderland, and L. D. Leake (1979) Effects of leech Retzius cells on body wall muscles. Comp. Biochem. Physiol. (C) 63: 359-361.

Massoulié, J., S. Bon, and M. Vigny (1980) The polymorphism of cholinesterase in vertebrates. Neurochem. Int. 2: 161-184.

McCaman, R. E., and S. D. Dewhurst (1971) Metabolism of putative transmitters in individual neurons of Aplysia culifornica. Acetylcholinesterase and catechol- $O$-methyl transferase. J. Neurochem. 18: 1329-1335.

Miledi, R., P. C. Molenaar, and R. L. Polak (1977) An analysis of acetylcholine in frog muscle by mass fragmentography. Proc. R. Soc. Lond. (Biol.) 197: 285-297.

Ort, C. A., W. B. Kristan, Jr., and G. S. Stent (1974) Neuronal control of swimming in the medicinal leech. II. Identification and connections of motor neurons. J. Comp. Physiol. 94: 121-
154.

Potter, L. T. (1967) A radiometric microassay of acetylcholinesterase. J. Pharmacol. Exp. Ther. 156: 500-506.

Potter, L. T. (1970) Synthesis, storage and release of $\left({ }^{14} \mathrm{C}\right)$ acetylcholine in isolated rat diaphragm muscles. J. Physiol. (Lond.) 206: 145-166.

Robinson, P. M. (1971) The demonstration of acetylcholinesterase in autonomic axons with the electron microscope. Prog. Brain Res. 34: 357-370.

Sargent, P. B. (1977) Synthesis of acetylcholine by excitatory motoneurons in central nervous system of the leech. J. Neurophysiol. 40: 453-460.

Sargent, P. B., K. -W. Yau, and J. G. Nicholls (1977) Extrasynaptic receptors on cell bodies of neurons in the central nervous system of the leech. J. Neurophysiol. 40: 446-452.

Silver, A. (1974) The Biology of Cholinesterase, North-Holland, Amsterdam.

Stewart, W. W. (1978) Functional connections between cells as revealed by dye-coupling with a highly fluorescent naphthalimide tracer. Cell 14: 741-759.

Stuart, A. E. (1970) Physiological and morphological properties of motoneurons in the central nervous system of the leech. $J$. Physiol. (Lond.) 209: 627-646.

Walker, R. J., G. N. Woodruff, and G. A. Kerkut (1968) The effect of acetylcholine and 5-hydroxytryptamine on electrophysiological recordings from muscle fibres of the leech $\mathrm{Hi}$ rudo medicinalis. Comp. Biochem. Physiol. 24: 987-990.

Walker, K. J., G. N. Woodruff, and G. A. Kerkut (1970) The action of cholinergic antagonists on spontaneous excitatory potentials recorded from the body wall of the leech, Hirudo medicinalis. Comp. Biochem. Physiol. 32: 691-701.

Wallace, B. G. (1981a) Distribution of AChE in cholinergic and non-cholinergic neurons. Brain Res. 219: 190-195.

Wallace, B. G. (1981b) Neurotransmitter chemistry. In Neurobiology of the Leech, K. J. Muller, J. G. Nicholls, and G. S. Stent, eds., pp. 147-172, Cold Spring Harbor Laboratory, Cold Spring Harbor, NY.

Wallace, B. G., and J. Gillon (1981) Intracellular AChE identifies cholinergic neurons. Soc. Neurosci. Abstr. 7: 913.

Wilbur, K. M., and N. G. Anderson (1948) Electrometric and colorimetric determination of carbonic anhydrase. J. Biol. Chem. 176: 147-154.

Willard, A. L. (1981) Effects of serotonin on the generation of the motor program for swimming by the medicinal leech. J. Neurosci. 1: 936-944. 